\title{
The predictive value of mean platelet volume, neutrophil lymphocyte ratio and platelet lymphocyte ratio in acute middle cerebral artery infarction patients
}

\section{Akut orta serebral arter enfarkt hastalarında ille ortalama trombosit hacmi, nötrofil lenfosit oranı ve trombosit lenfosit oranının prediktif değeri}

\author{
Hamit Celik ${ }^{1}$, Mesut Erbaș $^{2}$
}

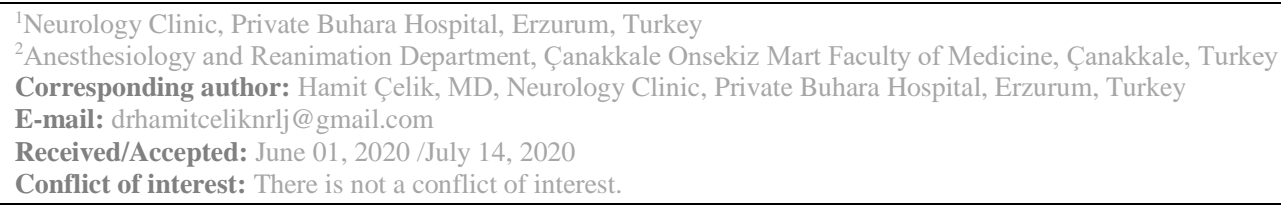

\section{SUMMARY}

Objective: The aim of this study was to determine the predictive value of mean platelet volume (MPV), neutrophil-to-lymphocyte ratio(NLR) and platelet-to-lymphocyte ratio(PLR) in patients with acute middle cerebral artery (MCA)branch infarction.

Method: This examination was performed on the files of 50 patients followed up at the Anesthesia and Reanimation ICU of Onsekiz Mart University Hospital between April 2017 and September 2019 for acute occlusion in the MCA branch, with no previous history of an ischemic stroke. These patients were assessed with the National Institutes of Health Stroke Scale (NIHSS) and the Modified Rankin Score (mRS). The ratios of the neutrophil and platelet countsto the lymphocyte count (NLR and PLR ratios) within the first hour of the stroke and MPV were compared to a control group.

Results: The study included 50 patients with the acute ischemia of the MCA branch, of which $28(56 \%)$ were female. The control group consisted of 50 healthy people, and $24(48 \%)$ of these were female. The mean NIHSS score of the patients was $11.4 \pm 2.6$, and their mean mRS was $2.5 \pm 1.5$.

Conclusions: In our study with patients who had acute middle cerebral artery infarction, we found that the NLR, PLR, and MPV levels within the first hour of stroke were higher in the patient group in comparison to the control group ona statistically significant level. However, multicenter studies with larger subject groups are needed for the use of hematological parameters as biomarkers in an ischemic stroke.

Keywords: Cerebral artery infarct, mean platelet volume, neutrophil, lymphocyte
ORCID IDs of the authors: H.Ç. 0000-0002-8654-2518 M.E. 0000-0003-3996-7094 
Amaç: T1kayıcı beyin damar hastalıklarında ortalama trombosit hacminin arttığı, lenfosit ve nötrofilerin iskemik hasarı artırdığı bilinmektedir. Çalışmamızda akut orta serebral dal enfarkı olan hastalarda ortalama trombosit hacmi, nötrofil lenfosit oranı ve trombosit lenfosit oranının prediktif değerini belirlemeyi amaçladık.

Yöntem: Nisan 2017-Eylül 2019 tarihleri arasında Çanakkale Onsekiz Mart Anestezi ve Reanimasyon yoğun bakımda takip edilen, daha önce iskemik inme geçirmemiş akut orta serebral arter dal tıkanıklı̆̆ı olan 50 hastanın dosyası geriye dönük olarak incelendi. Hasta grubu ulusal inme sağlı ölçeği skalası (NIHSS) ve Modifiye rankin skoru (mRS) kullanılarak değerlendirildi. İnmenin ilk saatindeki nötrofil ve trombosit sayısının lenfosit sayısına (NLO ve TLO oranı) oranının ve OTH (ortalama trombosit hacmi) düzeylerini Benzer yaş ve cinsiyette kontrol grubu ile karşılaştırdık.

Bulgular: Çalışmamıza akut orta serebral arter dal iskemisi olan 28'i kadın (\%56) olmak üzere 50 hasta alındı. Kontrol grubu ise yaşı ve cinsiyetiyle uyumlu 24'ü (\%48) kadın 50 sağlıklı kişi alındı. Hastaların ortalama NIHSS skoru $11.4 \pm 2.6$ ve ortalama mRS skoru $2.5 \pm 1.5$ idi.

Sonuç: Tıkayıcı beyin damar hastalıklarında hematolojik parametrelerin inmenin şiddeti ve prognozuyla ilişkisini inceleyen birçok çalışma vardır. Akut orta serebral arter dal infarktı geçiren hastalarla yaptığımız bu çalışmada inmenin ilk saatinde bakılan NLO, TLO, OTH düzeyini kontrol grubu ile kıyaslandığında istatiksel olarak anlamlı yüksek bulundu. Hematolojik parametrelerin iskemik inmede bir biyobelirteç olarak kullanılması için çok merkezli daha geniş katılımlı çalışmalara ihtiyaç vardır.

Anahtar sözcükler: Orta serebral arter dal enfarkt1, ortalama trombosit hacmi, nötrofil, lenfosit

\section{INTRODUCTION}

Stroke is a disease whose socioeconomic burden is constantly increasing, and morbidity rate is high especially in developing countries. Especially its high mortality rate and loss of function in survivors, as well as requirement of long-lasting support and care, increase the importance of early diagnosis and effective treatment of acute stroke. Approximately $87 \%$ of stroke patients have ischemic stroke, while $16 \%$ have hemorrhagic stroke (intracerebral hemorrhage and subarachnoid hemorrhages) ${ }^{1}$. For cerebral infarctions, several risk factors as age, sex, hypertension, diabetes mellitus, smoking, genetic factors and cardiac diseases may be listed ${ }^{2,3}$. Our knowledge on stroke is being updated day by day with various studies from different countries assessing data in the last three decades. Risk factors for cerebral infarctions may be listed as age, sex, race, hypertension, metabolic syndrome, diabetes mellitus, smoking, poor nutrition, alcohol consumption, sedentary life, genetic factors, obesity, psychiatric diseases, cardiac diseases, lipid metabolism disorder, air pollution, diseases causing chronic inflammation, sepsis and acute infection, chronic kidney failure, substance addiction and drug abuse, carotid stenosis and sleep breathing disorders ${ }^{2,3}$.

The middle cerebral artery (MCA) is one of the brain arteries that are frequently clogged in infarctions, and the clinical signs in the case of their clogging are very well-known. It is known that, if MCA clogging is not intervened with, intraparenchymal ischemia induces an irreversible injury in neurons. There is rapid deterioration in neurological signs in the first hours of stroke development in $25-40 \%$ of ischemic stroke patients. Looking at causes of neurological deterioration, extracellular glutamate increase, formation of cellular acidosis, cytokine secretion, free radical formation, nitric oxide production and intracellular calcium increase are among the possible mechanisms, whereas the area in the central nervous system innervated by the clogged artery is also highly important. Studies that have been conducted investigated the acute phase reactants, signal molecules, cytokines, interleukins, hormones and biomarkers that decrease or increase in acute ischemic stroke and their relationship to the prognosis of stroke ${ }^{4-5}$.

Recent studies have shown that the ratios of neutrophil and platelet counts to lymphocyte count (NLR and PLR ratios) and MPV (mean platelet volume) values may be an indicator of systemic inflammation, and they are related to the prognosis in several cardiovascular diseases, malignancies and chronic inflammatory diseases ${ }^{6-7}$. Neutrophil activation leads to secretion of reactive oxygen species, cytokines, proteases and cationic proteins (e.g. elastase, lactoferrin). In the case of an infarction in the region of the middle cerebral artery (MCA), the effects of the intensity of these inflammatory cytokines on the patient's prognosis become highly significant. A study conducted in Turkey demonstrated that NLR and PLR increased in the acute period in patients with intracerebral hemorrhage, and these may be associated with mortality ${ }^{8}$.

In our study, in patients that were hospitalized at the intensive care unit with a definite diagnosis of acute middle cerebral artery branch infarction who had not had an ischemic stroke before, we compared the neutrophil and platelet to lymphocyte 
ratios (NLR and PLR) and MPV (mean platelet volume) values to those in a control group.

\section{MATERIAL AND METHODS}

Our study included 50 patients who were admitted to the emergency service in the first 12 hours who were being monitored and hospitalized at our intensive care unit with the diagnosis of middle cerebral infarction between April 2017 and September 2019. The control group consisted of 50 healthy individuals who were admitted to the check-up polyclinic of our hospital.

Based on the information obtained from patient relatives and hospital records, patients with usage of drugs that alter platelet, lymphocyte or neutrophil counts, those with systemic or chronic inflammatory diseases, those at the stage of active infection, those with a recent history of trauma and surgical intervention or those with an acute MI picture, total middle cerebral artery, anterior cerebral artery infarction, posterior cerebral artery infarction patients, those with combined infarction of these arteries, patients with lacunar syndrome diagnosis, patients with history of previous stroke and those with liver failure, kidney failure or advanced heart failure were excluded from the study.

The study included 50 patients with acute middle cerebral artery branch infarction, 28 of whom were female. Blood samples were obtained and collected in hemogram tubes from all patients to measure their NLR, PLR and MPV levels in the first hour of stroke. All patients received neurological examination when they were admitted to the intensive care unit. The severity of stroke was determined by filling out NIHSS (National Institutes of Health Stroke Scale). At the time of admission, their cranial computerized tomography images were taken, and control CT imaging was performed on all patients at the 24th-48th hours. In this process, the patients received all necessary monitoring and follow up procedures at the intensive care unit, and all routine biochemistry and hemogram tests were carried out. For our study, approval was obtained from the local ethics board (Decision no: 2019-21).

\section{Statistical Analysis}

In our study, the SPSS (Statistical Package for the Social Sciences) Windows 19.0 package program was used for the statistical analyses. The data were analyzed by using descriptive statistical methods (mean, standard deviation). Student's t-test was used to compare the patient and control groups. The results were interpreted in a $95 \%$ confidence interval, and $\mathrm{p}<0.05$ was accepted as statistically significant.

\section{RESULTS}

Our study included 50 patients, 28 (56\%) of whom were female. The mean age of the patients was $70 \pm 13$, with a range of 57 to 83 . Among the 50 healthy individuals in the control group, 24 (48\%) were female. The mean age of the control group was $67 \pm 12$, with a range of 55 to 79 . The age and sex distributions of the control and patient groups were similar (Table 1). Among the 50 patients, 32 (64\%) had hypertension, while $22(44 \%)$ had diabetes. There was a history of cardiac disease in $24(48 \%)$ patients. Table 1 shows the demographic characteristics of the patient and control groups. In the patient group, according to the results of hemograms taken in the first hour of stroke, the neutrophil and platelet to lymphocyte ratios (NLR and PLR) were calculated, and the MPV (mean platelet volume) values were determined.

Table 1: Demographic Characteristics in MCA and Control Groups

\begin{tabular}{|l|l|l|}
\hline & MCA (n:50, \%) & Control (n:50,\%) \\
\hline Age (years) & $70 \pm 13$ & $6870 \pm 12$ \\
\hline Sex (F/M) & $56 / 44$ & $48 / 42$ \\
\hline Smoking & $60 \%$ & \\
\hline Hypertension & $64 \%$ & \\
\hline Diabetes mellitus & $44 \%$ & \\
\hline Cardiac disease & $48 \%$ & \\
\hline
\end{tabular}

The mean value of the NLR in the first hour of stroke in the patient group was $3.8 \pm 1.9$, while the mean NLR in the control group was $2.1 \pm 0.7$. There was a statistically significant difference in the NLR values between the patient and control groups $(\mathrm{p}<0.001)$. Table 2 shows the other clinical results in the patient and control groups. The patient group had an NIHSS mean score of $11.4 \pm 2.6(0-42)$, while their mean $\mathrm{mRS}$ was $2.576 \pm 2.100(0-6)$. 
Table 2: Clinical Characteristics in MCA and Control Groups

\begin{tabular}{|l|l|l|l|}
\hline & \multicolumn{1}{|c|}{ MCA } & Control & $\mathrm{p}$ \\
\hline NLR & $3.8 \pm 1.9$ & $2.1 \pm 0.7$ & $<0.005$ \\
\hline PLR & $159.4 \pm 13.4$ & $109.2 \pm 9.2$ & $<0.005$ \\
\hline MPV & $8.5 \pm 2.3$ & $5.9 \pm 2.1$ & $<0.005$ \\
\hline NIHSS mean & $11.4 \pm 2.6$ & & \\
\hline mRS mean & $2.5 \pm 1.5$ & & \\
\hline
\end{tabular}

\section{DISCUSSION}

In our study, the NLR, PLR and MPV levels in the first hour of stroke in the patients who had acute middle cerebral artery branch infarction for the first time were significantly higher than those in the control group.

It is thought that free oxygen radicals seen in ischemia, reperfusion, cellular acidosis and hypoxia processes lead to various structural changes in acute stroke patients. In recent years, it has been reported that neutrophilia and lymphopenia are independently related to increased cardiovascular risk. In particular, it was stated that the maximum NLR is one of the determining factors on mortality in myocardial infarction ${ }^{9,10}$.

Studies have reported that high MPV, NLR and PLR values are an independent risk factor and indicator of poor prognosis in malignancies, chronic inflammatory diseases and cardiovascular diseases such as myocardial infarction. MPV, NLR and PLR are easily measurable parameters ${ }^{11}$.

The inflammatory process develops right at the onset of ischemic stroke and as a response to ischemic brain injury; neutrophils rapidly migrate to the damaged area in the ischemic brain tissue. Studies reported that the basal neutrophil count is also important, and it may lead to poor neurological outcomes by increasing the severity of ischemic damage ${ }^{12}$. Moreover, the increase in lymphocytes starting after stroke and their peak on the seventh day show that especially $\mathrm{T}$ cell lymphocytes have a repairing effect on inflammation ${ }^{13}$. Higher neutrophil counts are considered together with lower lymphocyte counts which also result in low NLR values, and consequently, they indicate a highly damaged region with lower repair effects.

Buck et al. showed a significant relationship between the size of cerebral infarction and the increase in leukocyte and neutrophil counts ${ }^{14}$. Another study reported that there was an increase in leukocyte and neutrophil levels after temporary ischemic episode in patients with temporary ischemic episode ${ }^{15}$. Leukocytes are main cells that form a response to inflammation, cause endothelial damage and disrupt the antithrombogenic property of the endothelium ${ }^{16}$. Studies have demonstrated that, in humans, radioactively marked neutrophils rapidly gathered in the region of ischemia in 3-6 hours, and they reached the maximum levels within 12-24 hours. Leukocytes that pass into the ischemic region slow down the blood flow and form the phenomenon of postischemic reperfusion noreflow ${ }^{17}$. Leukocyte accumulation in the intravascular region disrupts the micro circulation, causing endothelial damage, and at the end, it may cause vasospasm and increase the severity of stroke. On the other hand, Beray-Berthat et al. ${ }^{18}$ showed that leukocyte increase may show a difference based on the damaged intracerebral region and the oxidative stress that develops, and different leukocyte responses may form in the experimental ischemic injuries in different intracerebral regions.

Greisenegger et al. ${ }^{19}$ revealed the relationship between MPV and stroke severity and determined that platelet reactivity increases by the severity of stroke. However, it should be kept in mind that the lifespan of platelets is short, the relationship obtained by these blood samples taken at the time of admission may be an acute phase reaction, and there may be a platelet dysfunction also in the prestroke period. In a study carried out in Turkey by Deveci et al., MPV was higher in comparison to the control group in the post-stroke acute period in ischemic stroke patients, and it may be that MPV anomaly is not an outcome of ischemic stroke but a significant factor for formation of ischemic stroke ${ }^{20}$. In a multicenter study conducted by Bath et al. with 3134 voluntary participants with a history of cerebrovascular disease, it was revealed that high MPV levels are an independent risk factor for recurring strokes ${ }^{21}$.

Previous studies have shown that some hemogram parameters that may be markers of inflammation and hypoxemia are associated with episodes and stroke. While the mean platelet volume is an 
indicator of platelet function and activation, it is also directly affected by inflammation ${ }^{22}$. There is a low number of studies that investigated hemogram parameters in this group of patients who experience acute neurological defect. Özaydın et al. proposed the mean platelet volume as a marker of the differentiation of simple and complex febrile episodes ${ }^{23}$. In a prospective study, epilepsy patients were compared to healthy control both during episodes and in the remission period, and the mean platelet volume values were determined to be higher in comparison to the control group in the patient group during episodes and in the period without episode activation ${ }^{24}$.

The fact that the number of patients in our study was low, that they were assessed with different inflammatory parameters and that clinical correlation could not be evaluated alongside repeated measures may be considered as the limitations of our study.

Consequently, in this study we conducted with patients who had acute middle cerebral artery branch infarctions, the NLR, PLR and MPV levels checked in the first hour of stroke in the patients were significantly higher than those measured in the control group. We believe that there is a need for further studies with a higher participation rate showing that these parameters may be used as a biochemical marker supporting the diagnosis of patients with negative imaging results but showing clinical signs especially in the first 24 hours.

\section{REFERENCES}

1. Benjamin EJ, Virani SS, Callaway CW, et al.and On behalf of theAmerican Heart Association Council on Epidemiology and Prevention Statistics Committee and Stroke Statistics Subcommittee. Heart Disease and Stroke Statistics-2018 Update: A Report From the American Heart Association. Circulation. 2018;137:e67-e492

2. Boehme AK, Esenwa C, Elkind MS. Stroke Risk Factors, Genetics, and Prevention. Circulation Research. 2017;120:472-495.

3. Utku U, Çelik Y. İnmede etiyoloji, siniflandirma ve risk faktörleri. Balkan S (Editör). Serebrovasküler Hastalıklar. 2. bask1. İstanbul: Günes Kitabevi; 2005: p.57-72.

4. Gray, C. S. French, J. M., James, O. F, Bates, D, \&Cartlidge, M. E. (1988). Theprognosticvalue of haematocrit in acutestroke. Age andageing, 17(6), 406-409.

5. Talwalkar SS, Bon Homme M, Miller JJ et al. Ischemiamodifiedalbumin, a marker of acuteischemicevents: a pilot study. AnnClinLabSci. 2008; 38 (2):132-7.
6. Buyukkaya E, Karakas MF, Karakas E, et al: Correlation of neutrophiltolymphocyteratio withthe presence andseverity of metabolicsyndrome. ClinApplThrombHemost 2014;20:159-63.

7. Imtiaz F, Shafique $K$, Mirza SS, et al: Neutrophil lymphocyte ratio as a measure of systemic inflammation in prevalent chronic diseases in Asian population. Int Arch Med. 2012 Jan 26;5(1):2. doi: 10.1186/1755-7682-52.

8. Bolayir A, Bolayir H. The Effect of PlatelettoLymphocyteRatio on Mortality in Patients with Acute Intra cerebral Hemorrhage Bozok Med J 2018;8(1):75-81)

9. Kazmierski R, Guzik P, Ambrosius W, Ciesielska A, Moskal J, Kozubski W. Predictivevalue of White bloodcellcount on admissionfor in-hospitalmortality in acutestrokepatients. ClinNeurolNeurosurg 2004;107:38-43.

10. Beray-Berthat V, Palmier B, Plotkine M, Margaill I. Neutrophils do not contributetoinfarction, oxidativestress, and NO synthaseactivity in severe brainischemia. ExpNeurol 2003;182:446-54.

11. Güldiken B., Özkan, H., \&Kabayel, L. (2008). Akut iskemik inmede ortalama trombosit hacmi ve periferik kan hücre sayısı yanıtı. Balkan MedicalJournal, 2008(2), 130-135.

12. Tokgoz S, Keskin S, Kayrak M, Seyithanoglu A, Ogmegul A. Is neutrophil/lymphocyteratiopredicttoshorttermmortality in acutecerebralinfarctindependentlyfrominfarctv olume? J StrokeCerebrovascDis 2014; 23: 2163-8.

13. Schwartz M, Moalem G. Beneficialimmuneactivityafter CNS injury: prospectsforvaccination. J Neuroimmunol 2001; 113: 185-92.

14. Buck BH, Liebeskind DS, Saver JL, Bang OY, Yun SW, Starkman S, et al. Earlyneutrophilia is associatedwithvolume of ischemictissue in acutestroke. Stroke 2008;39:355- 60.

15. Ross AM, Hurn P, Perrin N, Wood L, Carlini W, Potempa K. Evidence of theperipheralinflammatoryresponse in patientswithtransientischemicattack. StrokeCerebrovascDis 2007;16:203-7.

16. Pantoni L, Sarti C, Inzitari D. Cytokinesandcelladhesionmolecules in cerebralischemia: experimentalbasesandtherapeuticperspectives. ArteriosclerThrombVascBiol 1998;18:503-13.

17. Mori E, del Zoppo GJ, Chambers JD, Copeland BR, Arfors KE. Inhibition of 
polymorphonuclearleukocyteadherencesuppres sesno-reflowafterfocalcerebralischemia in baboons. Stroke 1992;23:712-8.

18. Beray-Berthat V, Croci N, Plotkine M, Margaill I.

Polymorphonuclearneutrophilscontributetoinfa rctionandoxidativestress in thecortex but not in thestriatumafterischemia-reperfusion in rats. Brain Res 2003;987:32-8.

19. Greisenegger S, Endler G, Hsieh K, Tentschert S, Mannhalter C, Lalouschek W. Is elevatedmeanplateletvolumeassociatedwith a worseoutcome in patients with acute ischemic cerebro vascular events? Stroke 2004;35:168891.

20. Deveci Ş. Çelebi A. Aşkın S. Gürsoy A E, Kolukısa M ,Hakyemez A. Akut iskemik inme ile ortalama trombosit hacmi ilişkisi. Ege tıp dergisi 2014;53(1):1-6.

21. Bath P, Algert C, Chapman N, Neal B; PROGRESS CollaborativeGroup.Association of meanplateletvolumewith risk of stroke a mong 3134 individuals with history of cerebrovascular disease.Stroke. 2004 Mar;35(3):622-6. Epub 2004 Feb 19.

22. Bath PM, Butterworth RJ. Platelet size: measurement, physiology and vascular disease. Blood Coagul Fibrinolysis 1996;7(2):157-61

23. Ozaydin E, Arhan E, Cetinkaya B, Ozdel S, Değerliyurt A, Güven A, et al. Differences in iron deficiency anemia and mean platelet volume between children with simple and complex febrile seizures. Seizure 2012;21(3):211-4

24. Eroglu T, Aydin Turkoglu S, Bolac ES, Yildiz S, Yildiz N. Hemogram parameters in epilepsy may be indicators of chronic inflammation and hypoxemia. J Neurol Clin Neurosci 2017;1(1):17-20 